University for Business and Technology in Kosovo

UBT Knowledge Center

UBT International Conference

2013 UBT International Conference

Nov 1st, 2:30 PM - 2:45 PM

\title{
Santiago Calatrava, City of Arts and Science: The Similarity of the Elements
}

Ani Tola

Polytechnic University of Tirana, apanariti@hotmail.com

Armand Vokshi

Polytechnic University of Tirana, armandvokshi@gmail.com

Follow this and additional works at: https://knowledgecenter.ubt-uni.net/conference

Part of the Architecture Commons

\section{Recommended Citation}

Tola, Ani and Vokshi, Armand, "Santiago Calatrava, City of Arts and Science: The Similarity of the Elements" (2013). UBT International Conference. 3.

https://knowledgecenter.ubt-uni.net/conference/2013/all-events/3

This Event is brought to you for free and open access by the Publication and Journals at UBT Knowledge Center. It has been accepted for inclusion in UBT International Conference by an authorized administrator of UBT Knowledge Center. For more information, please contact knowledge.center@ubt-uni.net. 


\title{
Santiago Calatrava, City of Arts and Science: The Similarity of the Elements
}

\author{
Ani Tola ${ }^{1}$, Armand Vokshi ${ }^{1}$ \\ apanariti@hotmail.com; armandvokshi@gmail.com \\ 1 Polytechnic University of Tirana \\ Faculty of Architecture and Urbanism \\ Tirana, Albania
}

\begin{abstract}
This paper presents a description of the buildings of the City of Arts and Science and defines the key elements that Calatrava uses in the designing of this complex. In the beginning is presented a general description of the City of Arts and Science. A further analysis is been done for each building, which is based in the context of the concept that Calatrava uses. Also is done an analysis in the context of shape, structure and materials, which are very connected with the concept of the architect. In the end, are analyzed also the elements that are similar with his prior projects and how they have been developed. These elements also have been served for his recent work.

The paper concludes that the key elements that Calatrava uses in this complex are almost the key element that Calatrava has been used in the other prior projects. These key elements which are also present in its recent works, creates the design vocabulary that Calatrava uses in his projects.
\end{abstract}

Keywor ds: Calatrava's geometric shapes, design's elements, structure.

\section{Introduction}

This paper introduces a description of the buildings of the City of Arts and Science and defines the key elements that Calatrava uses in the designing of this complex.

The opening provides a general description of the City of Arts and Science. The city of Arts and Sciences is an urban recreation center of culture and science that was completely developed by Santiago Calatrava. It also incorporates L'Oceanogràfic, an underwater city designed by the late Felix Candela. This complex is made up by seven building such as, L'Hemisfèric, The Science Museum Principe Felipe, L'Umbracle, El Palau de les Arts Reina, L'Oceanogràfic, the bridge El Pont de l'Assut de l'Or and the last but not least, L'Àgora.

After that, it describes each of the composing buildings. It contains general information for each building and describes the architectural and engineering concepts and elements.

A further analysis has been done for each of the composed buildings. This analysis is based in the context of the concept that Calatrava uses, such as the human being and nature. It also gives an analys is in the context of shape, structure and materials, which are connected to each other and the concept of the architect.

In the end, it also analyses the elements that are similar to each other and his prior projects and how they have been developed. These elements have also been compared to his recent work.

\section{City of Arts and Science}

"As the site is close to the sea, and Valencia is so dry, I decided to make water a major element for the whole site using it as a mirror for the architecture." 
In 1991 Calatrava won a competition for a telecommunication tower to be built on a 35 hectares site located in the old dried-up river bed of the Turia, midway between the old city of Valencia and the coastal district of Nazaret. In 1957, there was a disastrous flood, so the river was diverted along a canal to the south of the city, and the dried-out riverbed planted as a 7 kilometer long promenade through the center of the city. The promenade is crossed by two streamlined new bridges designed by Santiago Calatrava. Calatrava subsequently received the commission to develop the whole complex, which was to be called The City of Arts and Science and would include a planetarium and a science museum. After a change of government in 1996, the planned telecommunication tower was replaced by an opera house. The city of Arts and Sciences is an urban recreation center for culture and science, which was completely developed by Santiago Calatrava. It also incorporates L'Oceanogràfic, an underwater city designed by the late Felix Candela with an area of 350,000 square meters. The client of the project was the government of Valenzia and the project underwent the first.

Calatrava's work appears to have been strongly influenced by the work of Gaudí. His highly organic, almost anthropomorphic forms are all based on his structural studies. The skeletal concrete forms are in many ways similar to Gaudí's stone and masonry constructions, but there is a difference. While Gaudí's work was always charged with a highly developed sense of materiality, Calatrava abstracts his materials, preferring a white finish that homogenizes the elements of the construction.

\section{Architect's Biography}

"Santiago Calatrava Valls was born on the 28th of July 1951 in Benimàmet, an old municipality now integrated as an urban part of Valencia, Spain. He is a Spanish architect, sculptor and structural engineer whose principal office is in Zürich, Switzerland.

In Valenzia, he pursued his undergraduate architecture degree at the Polytechnic University of Valencia along with a post-graduate course in urbanism. During his schooldays, he also undertook independent projects with a group of fellow students, bringing out two books on the vernacular architecture of Valencia and Ibiza. Following graduation in 1975, he enrolled in the Swiss Federal Institute of Technology in Zürich, Switzerland, for graduate work in civil engineering. In 1981, after comp leting his doctoral thesis on "The Foldability of Space Frames", he started his architecture and engineering practice.

Calatrava's early career was mainly dedicated to bridges and train stations, with designs that elevated the status of civil engineering projects to new heights. His Montjuic Communications Tower in Barcelona, Spain (1991) in the heart of the 1992 Olympics site, as well as the Allen Lambert Galleria in Toronto, Canada (1992), were important works and turning points in his career, leading to a wide range of commissions. The Quadracci Pavilion (2001) of the Milwaukee Art Museum was his first building in the United States. Calatrava's entry into high-rise design began with an innovative 54-storyhigh twisting tower called Turning Torso (2005), located in Malmö, Sweden. Calatrava has also designed a futuristic train station, the World Trade Center Transportation Hub, at the rebuilt World Trade Center in New York City.

His style has been heralded as bridging the division between structural engineering and architecture. In his projects, he continues a tradition of Spanish modernist engineering that included Félix Candela, Antonio Gaudí, and Rafael Guastavino. Nonetheless, his style is also very personal and derives from numerous studies of the human body and the natural world.

\section{The Key Elements of the City of Arts and Sciences}

\subsection{L'Hemisfèric (Planetarium)}

Completely designed by Santiago Calatrava, this building was the first one that was opened to the public in April 1998. L'Hemisferic is the centerpiece of this complex, with a surface of 13,000 m2. Its position 
in the site is very well thought by the architect, as it is set in a slightly below grade to avoid the conflict of the view with the two others buildings, "Science Museum" and "Palacio de las Artes".

The building is meant to resemble a giant eye, is also known as the "Eye of knowledge". Taking a look to Calatrava's sketches, we can easily read that his inspiration for the concept of this building was the eye.

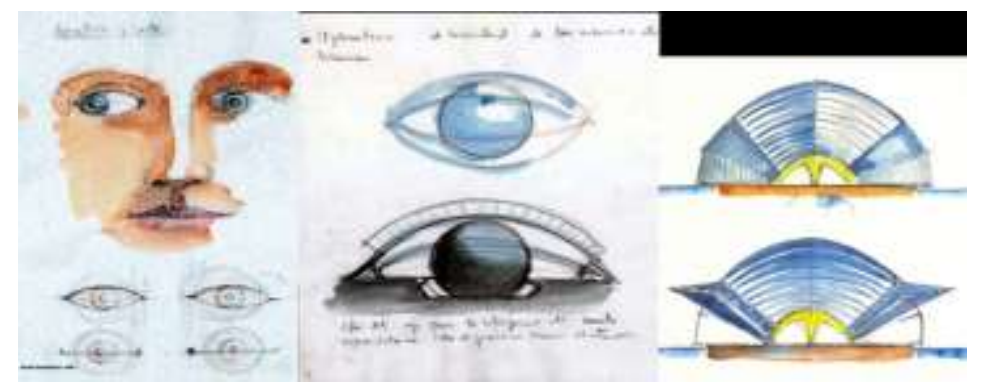

Fig. 1. Calatrava's Sketches

The whole shape of the eye will be drawn by a mirror plan, which will be the surface of the water. The building is surrounded in all of its parts by a water pool, and the bottom of the pool is made of glass. The accessibility from the building to the pool is made up of two sides that are the curved axes of the "eye". These two sides are designed as the eyelid, which opens and closes to create this access with the water pool and they also serve as a shade-shutter. The structure of the "eyelid", the shutter, is built by aluminum awnings alongside the perimeter that fold upward collectively or as individual units. This structure of the shutter forms the brise-soleil roof that opens alongside the elliptical axis of the eye. The brise-soleil is moved hydraulically up the outside of the structure by telescoping cylinders. When this brise-soleil is opened, we can see the dome that is conceived as the pupil of the eye.

In "The Dome" part of the Hemisferic are designed the IMAX Cinema, Planetarium and a Laserium. This planetarium is a half-sphere composed of concrete 110 meters long and 55.5 meters wide. The IMAX Theater's spherical exterior is vestured in fragments of shattered tiles. The structural concrete and steel shell creates a vault above the planetarium. The concrete encasement is extended upwards to the other parts of the "eye", in which are the entrances for the building. In those parts, the brise-soleils of the "eyelid" shutter are narrowed and replaced by a slat structure in the both sides of pivoting point of the concrete shell. They imitate the structure of a feather.
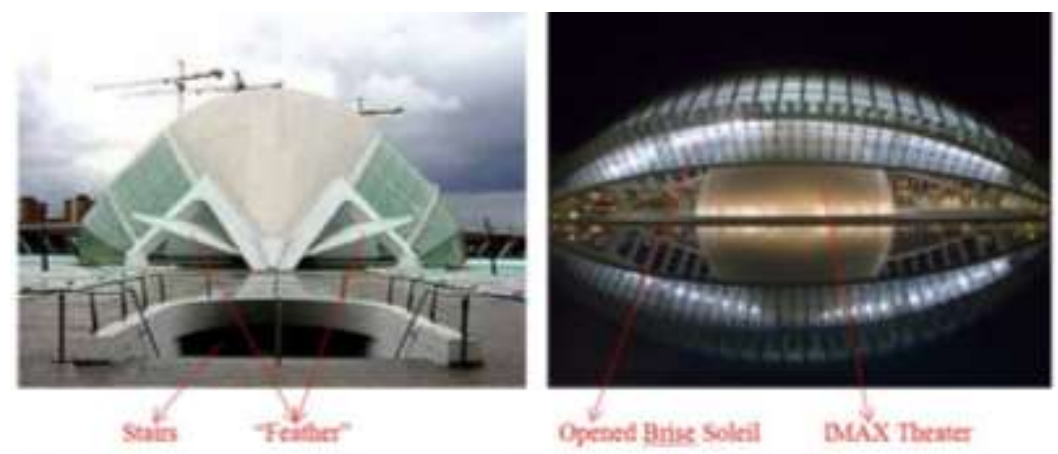

Fig. 2 L'Hemis fèric - Brise Soleil

\section{Which are the Key Elements that Calatrava uses in the design of the L'Hemispheric?}

There are three main elements which Calatrava used in the L'Hemispheric; the Eye, the Brise-Soleil and the Swooping Anchor.

Through the metaphor of an eye, the architect's eye is frequently present in the work of Calatrava. The planetarium is the most explicit reference to the human eye, and his sketches for the project make this 
link clear. He always expresses the relation between human body and architecture. The eye shape element was present in the other prior projects that Calatravas uses before designing the L'Hemisferic. The half sphere necessary for the projection of IMAX movies is the kind of geometric form that stimulates the imagination of Calatrava. It also represents the human eye, and also the sphere of the cosmos.

The movement of the structural elements that Calatrava uses is present in this project in the Brise Soleil, which serves as a sunshade for the building. Also this element further heightens the expression of his fascination with vision.

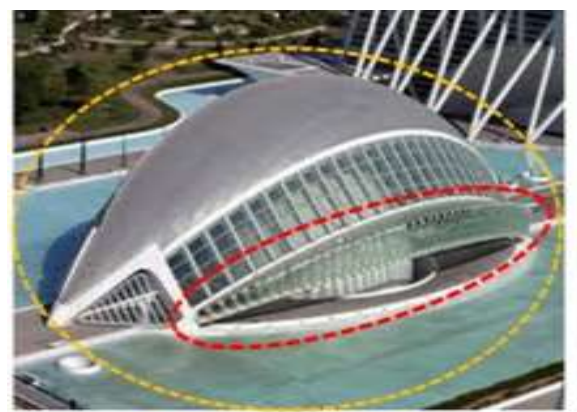

Folded Brise Soleil, Eye shape; L'Hemisferic

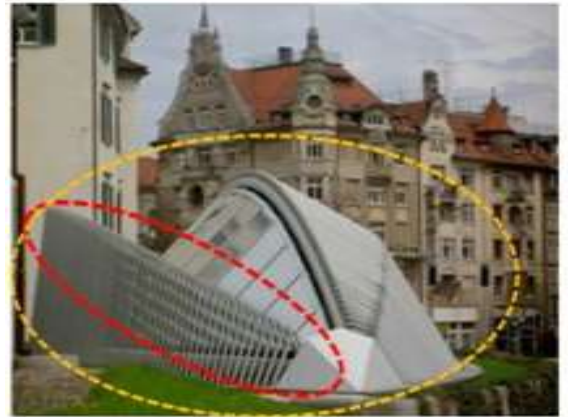

Folding Roof, Eye Shape; Emergency Service Center Folded elements

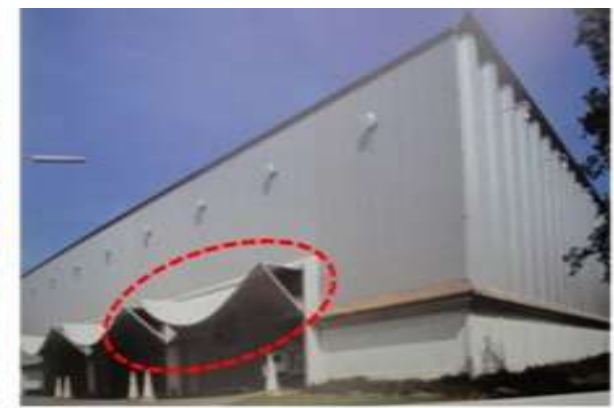

Folding Doors, Ermsting Wearhouse

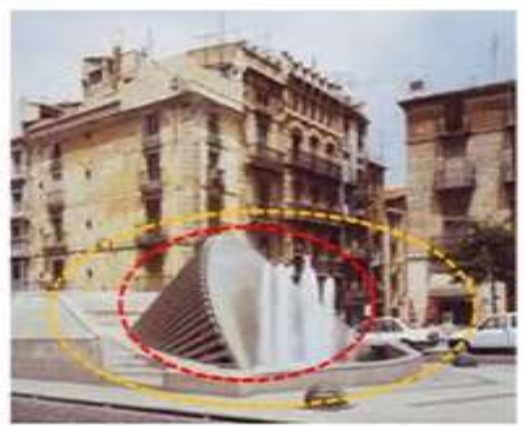

Stainless Steel Folding, Eye Shape; Alcoy

Community Hall

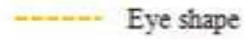

Fig. 3 Folded elements, Eye shape

The movement of Brise Soleil structure has similarity with other projects that Calatrava uses in his prior designs. The mechanic movement that Calatrava uses in these folded elements is an essential tool for L'Hemis feric also. The folding elements Calatrava uses in other projects, such as Ermsting Wearhouse, Emergency Service Center, Kuwait Pavilion. He developed this mechanism, not only to move in one direction, but each element moves independently from each other. It means that they move in a different direction of the vertical plan. The elements that Calatrava uses to design his projects have been a basement and also a design for the next project of Alcoy Community Hall. He uses the folding elements which are the Stainless steel folding of the fountain, and also he designs his fundamental shape as it is the eye.

The swooping anchor of the structure may bring to mind the one of the Lyon-Saint Exupery Airport Station but the French design is not included here. At this point he shows his strong engineering skills. Inspired from the physical concept of anchoring, he uses the swooping anchor as a key tool of his structures. 


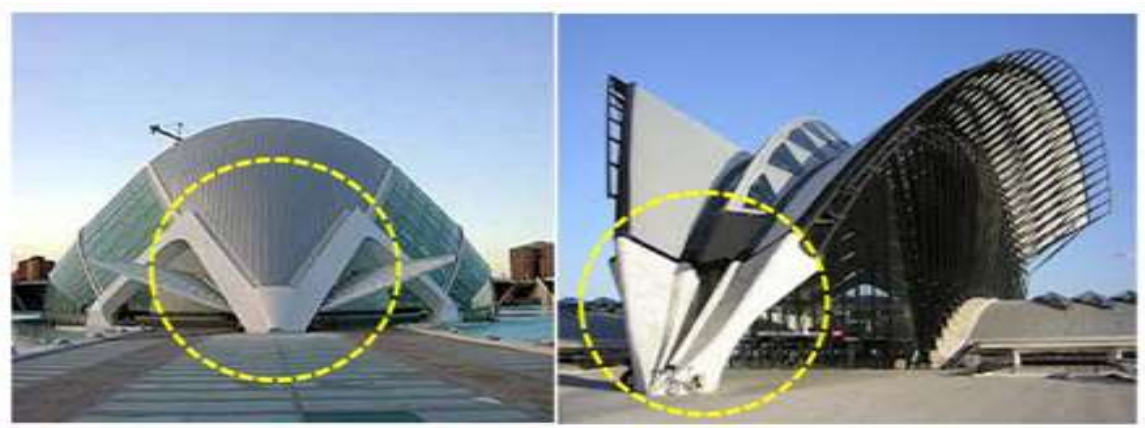

Swooping Anchor; L'Hemisferic

Fig. 4. Swooping anchor

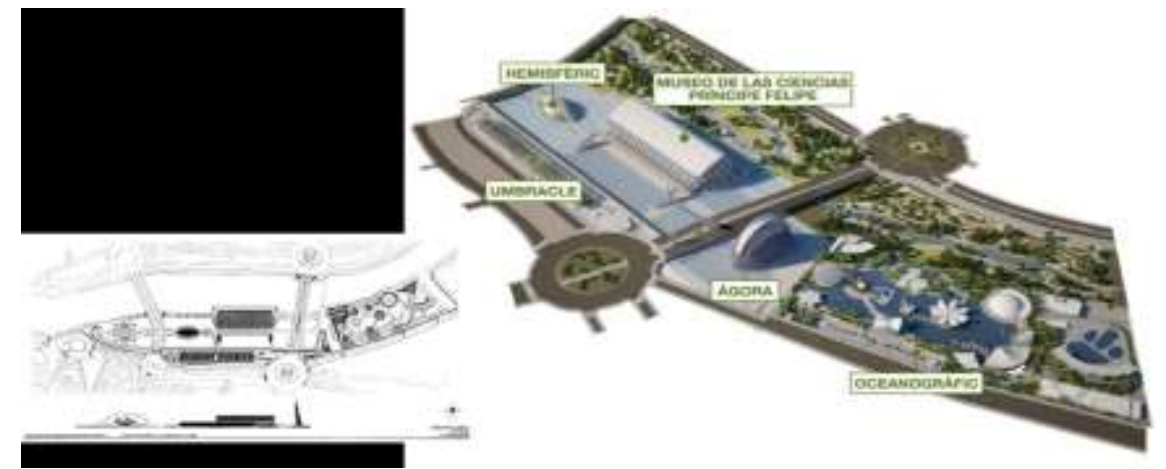

Fig. 5. City of arts and science, Seven Buildings

\subsection{The Science Museum Principe Felipe}

The second principal building is The Science Museum Principe Felipe, which is also completely designed by Santiago Calatrava. It is designed in 1991-1995 and constructed 1996-2001. Its surface occupies around $40,000 \mathrm{~m}^{2}$ on three floors. The building is made up of three floors of which 26,000 square meters are used for exhibitions, which is currently the largest in Spain. The first floor has a beautiful view of the Turia Garden that surrounds it; which is over 13,500 square meters of water. In the second floor is "The Legacy of Science", an exhibition by the researchers; Santiago Ramón y Cajal, Severo Ochoa y Jean Dausset. The third floor is known as the "Chromosome Forest", which shows the sequencing of human DNA.

Also on this floor are the "Zero Gravity," the "Space Academy," and "Marvel Superheroes" exhibitions. This magnificent building stands 220 meters long, 80 meters wide and 55 meters high. It looks just like a brilliant idea, from a very innovative mind of Calatrava. The sunken garden extends beneath the walkway to optically connect the museum to the administrative buildings. The shape of the building resembles the skeleton of a whale. The structure of the building demonstrates the skeleton and is the only architectural element. This prehistoric skeleton is designed by the repetition of the one element, which is like the bone of the skeleton. This element serves as a modular that is repeated in constant distance from each other in the direction of the longitude of the building. They are the primitives of the shape for this building. The symmetrical ends of the building are braced firmly by triangulated structures which also mark the entrances.

Calatrava uses only three materials: white concrete that is the skeleton, the glass that gives transparence all the building, and the steel, which is the structure of the glass. The building's architecture is known for its geometry, structure, use of materials, and its design around nature. The white supporting concrete framework of the south-facing facade is filled with glass. The north facade is a glass and steel screen that forms a continuous curtain along the full length of the building. This is a modular development of 104 meters width and 241 meters in length. 


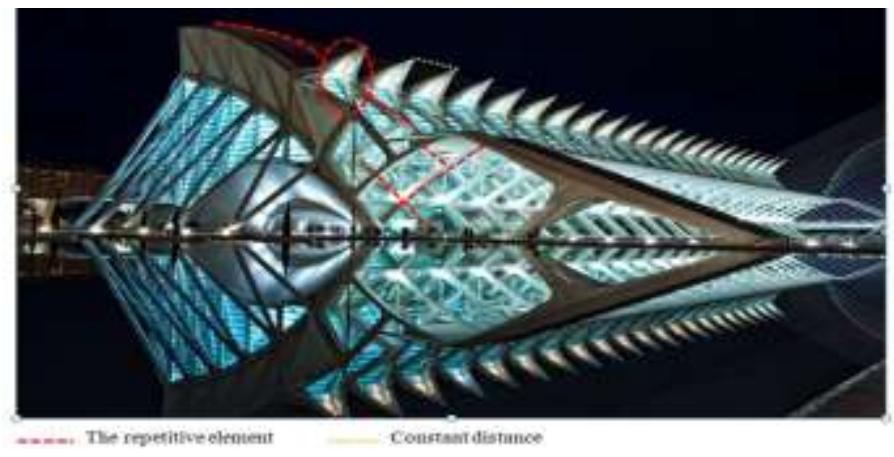

Fig. 6. The repetitive element, constant distance

Which are the Key Elements that Calatrava uses in the design of the Science Museum Principe Felipe?

There are three main elements which Calatrava used in Museum Principe Felipe; the Eye, the Tree structure and the Bones and Skeleton.

The eye shape always remains a key element in Santiago Calatrava's work. He also uses the shape of the eye, in a smaller scale in the Science Museum Principe Felipe than the base shape of L'Hemisferic. This building is just like a miniature of the Hemisferic. Also in the center of it are designed even the brise-soleil, which are the eyelid of Hemisferic, as the pupil of the eye in this building.
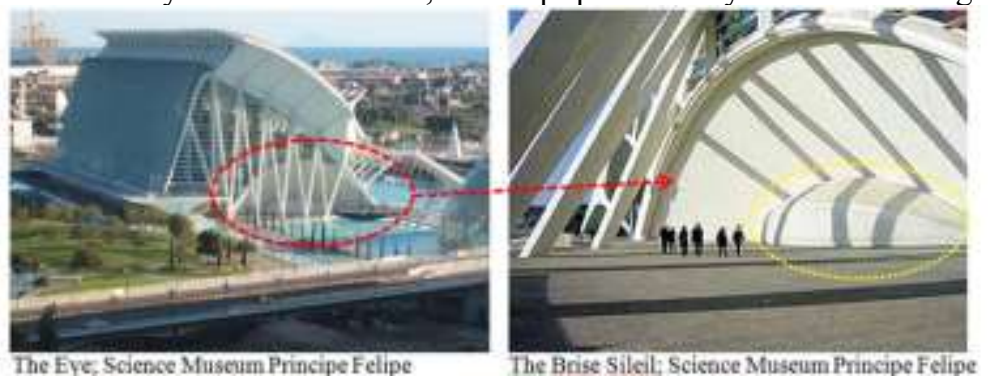

Fig. 7. The Eye shape

The building is based on an asymmetrical repetition of tree and rib like forms filled with glass to admit ample daylight. The North hall which is 40 meters has the proportions of a soaring Gothic cathedral nave. It has flying ribs and a waving glass wall running the full length of the building. The concrete "trees" are organized by five linearly concrete elements as the branches of the "tree", which supports the connection line between roof and facade on a scale that permits the integration of service cores and lifts.
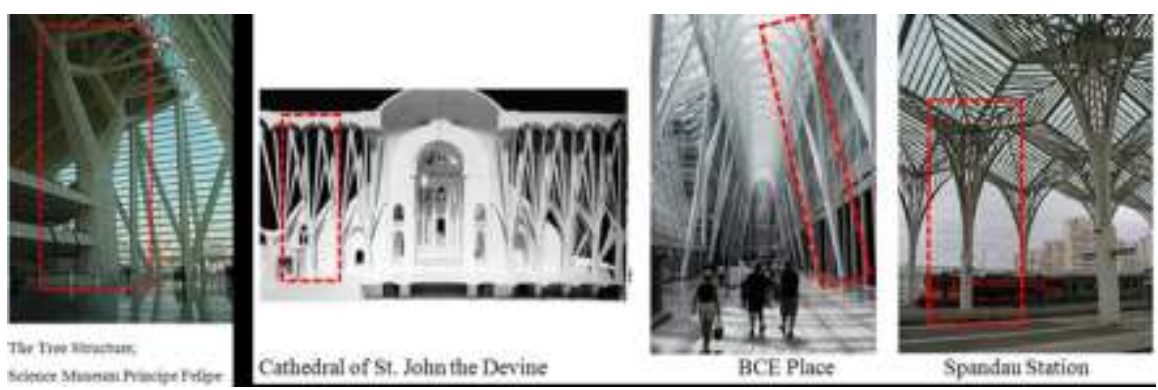

Fig. 8. The Tree Structure

The tree element that he uses in this building is also used and in other projects such as Cathedral of St. John the Devine, BCE Place, and Spandau Station. Also the tree structure has been a base element in the latest projects of Calatrava, such as Oriente Station. 
Another characteristic that defines the elements of Santiago Calatrava are the bones and skeleton. The architect is not only inspired by the human skeleton, but also by the animals' one, such as the whale skeleton in this project. Other projects in which Calatrava resembles the concept of the bones are the Kuwait Pavilion and the Shadow Machine, in which he worked in 1991-1992. The difference between those two projects and the Science Museum Principe Felipe is that in them Calatrava is using and the concept of movement. But in the Science Museum Principe Felipe, Calatrava constructed the skeleton just statically, there is no movement. Also another difference is that in the two otherprojects he is using a part of the human skeleton, such is the hand's bones. There he expresses the movement of the fingers .

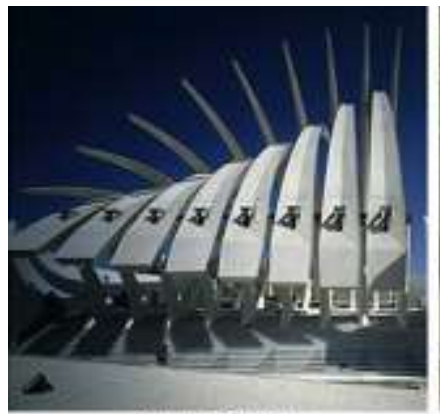

Kuwait Pavilion

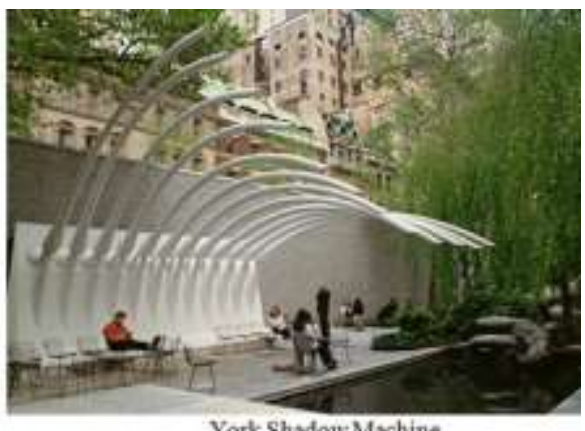

York Shadow Machine

Fig. 9. The bones and skeleton

\subsection{L'Umbracle (Parking Structure)}

L'Umbracle (Promenade and Car Park), which is located on the Southern facade of the complex, is the latest contribution of Santiago Calatrava's to the unique and comprehensive comp lex of the City of Arts and Sciences. The L'Umbracle was designed during 1995-1997 and constructed from 1997 until 2001, when it was opened to the public. The 320 meter long and 60 meter wide structure houses parking spaces for 900 cars and 20 busses. The promenade that is in the upper level has a surface of 50,860 m2. The Umbracle is a space that is a home to numerous sculptures surrounded by nature. It harbors in its interior The Walk of the Sculptures, an outdoor art gallery with sculptures from contemporary artists. It was designed as an entrance to the City of Arts and Sciences.

The upper part comprises a long panoramic promenade, with a tree-lined garden, from where there is a superb view of the Complex as a whole. Its 55 fixed arches and 54 floating arches that stand 18 meters high make the "umbrella" of the garden. The plants in the garden were carefully picked to change color with the seasons. L'Umbracle is intended as "a contemporary reinvention of the winter garden". The arches structure is made by steel construction, and they are identical from the beginning to the end. Also in this building we have an element that repeats in the longitude direction, with a constant distance. The material that Calatrava uses in this project is the steel structure and it is white colored. This is a very transparent structure because it lacks solid surfaces as well as the use of glass.

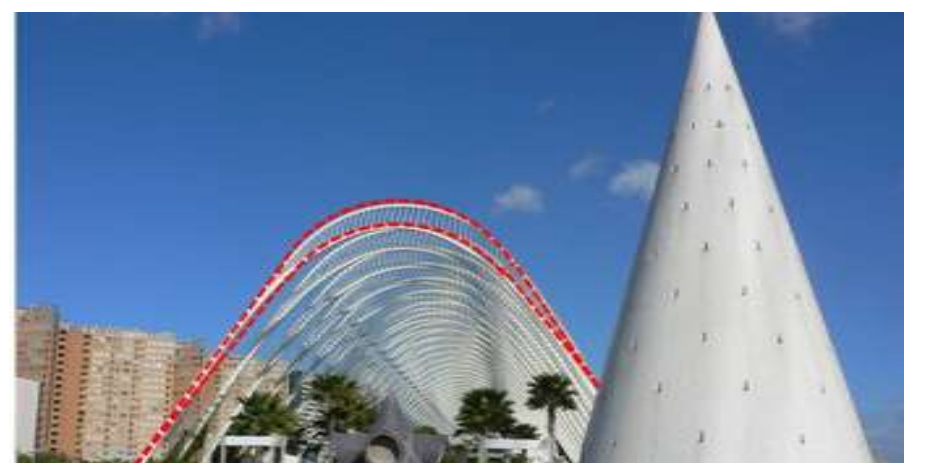


Fig. 10. L'Umbracle

Which are the Key Elements that Calatrava uses in the design of The L'umbracle?

The tree elements that he uses in this building are; the steel arches, the tree pillars, the mosaic tiles.

The concept of the Tree Pillars that Calatrava had been designed in the BCE Place and the Steel Arch which joints the pillars, have been used and in the construction of the L'Umbracle's Promenade. With the same logic Calatrava has designed his next project which is Olympic Game's Promenade.

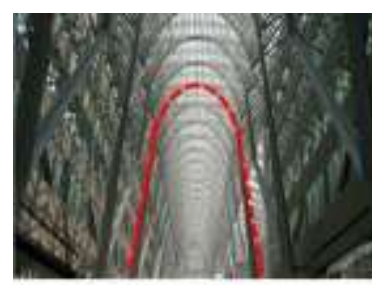

BCE Place

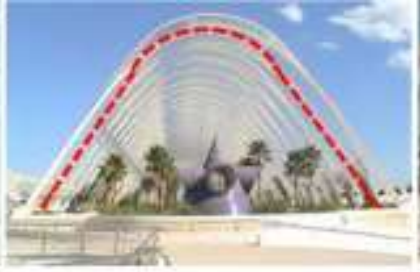

L'Umbracle's Promenade

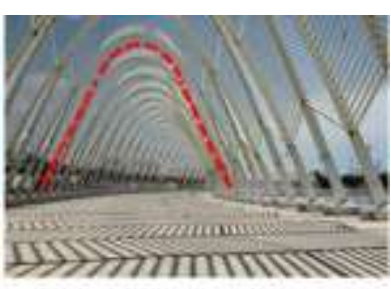

Olympic Game's Promenade

Fig. 11. The steel arches

In the parking level, Calatrava is using his tree pillars and they seem that they are not only as o constructive solution, but they also stand in harmony with the function of the upper level. The way how they are positioned in the tree pillars, is based on the earlier studies that Calatrava has done for the Oriente Station in which the architect sketches the trees of a dense forest.

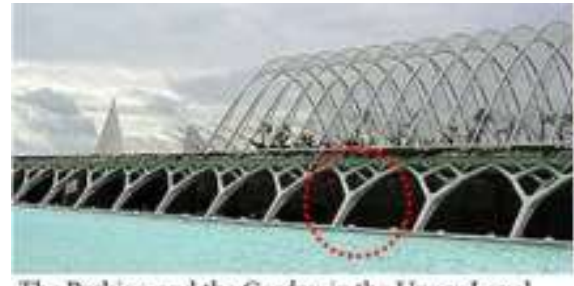

The Parking and the Garden in the Upper Level

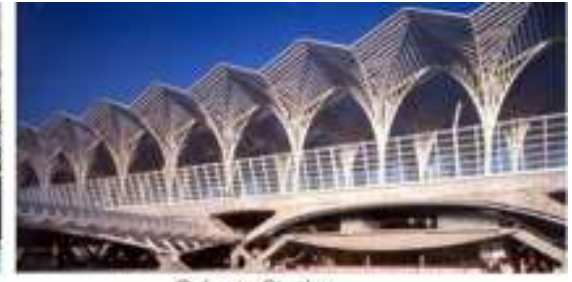

Oriente Station

Fig. 12. Tree pillars

For the aspiration of the parking level and for daylight Calatrava is using the conic volumes, which are intersected by spherical volumes. In the circular open surface of the conic surface, the architect uses blue mosaic tiles. We can see the influence of the Gaudi's style. 


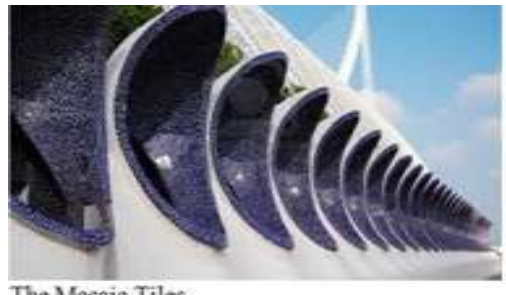

The Mosaic Tiles

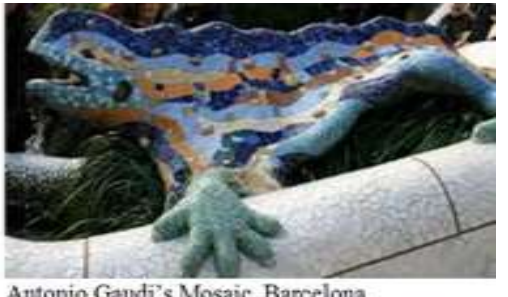

Antonio Gaudi's Mosaic, Barcelona

Fig. 13. Mosaic tiles

\subsection{Palacio De Las Artes Reine Sofia}

The Palacio de las Artes Reine Sofia is an opera house and performing arts center. Its surface is around $44,000 \mathrm{~m} 2$, and is 75 meter tall. The building is designed completely by Santiago Calatrava during 1995-1997, and is constructed during 1997-2005. In April of 2005 it was opened to the public. It contains four large rooms: a Main Room, Magisterial Classroom, Amphitheater and Theater of Camera. It is dedicated to music and the scenic arts. The Palau de Les Arts has four sections; the main hall, the master hall, the auditorium, and the Martin y Soler theatre. It holds many events such as opera, the atre and music in its auditoriums. The building has a metallic feather outer roof that rests on two supports and is 230 meters long and 70 meters high. One of the supports allows for part of the building to overhang. The building is supported by white concrete. Two laminated steel shells cover the building weighing over 3,000 tons. These shells are 163 meters wide and 163 meters long.

The Palacio de las Artes Reine Sofia was conceived as a series of casual volumes which have been unified through their enclosure within two symmetrical shells. The shells are made by concrete and are cut-away, to be crowned by a sweeping steel sheath that project axially from the entrance concourse out over the uppermost contours of the curvilinear envelope. This genius struct ure defines the identity of the Palacio de las Artes Reine Sofia. The symbolic of the seashell that Calatrava resembles, presents a dynamic effect as a signal in the landscape. While walking in the promenade by outside, the different volumes looks like they are stacked between the horizontal decks off the side of the structure. The nucleus part of the building is occupied by the technical facilities, such as the scenery module and lifting mechanisms for the stage and orchestra's pit of the opera house, and its fully air-conditioned auditorium, which seats 1300, is set within an acoustically shaped shell embedded within the cluster. In these different services, there is also a smaller auditorium, which is conceived mainly for chamber music concerts, seats 400 , and a large auditorium to the east, which is partially protected beneath the open shell and can seat around 2000 people.
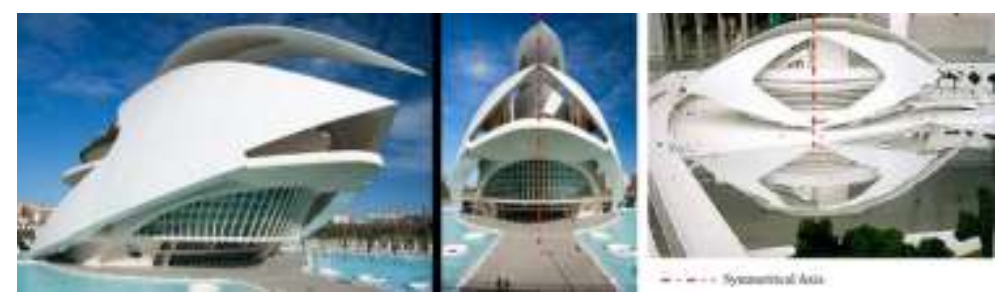

Fig. 14. Palacio de las Artes Reine Sofia

Which are the Key Elements that Calatrava uses in the design of The Palacio De Las Artes Reine Sofia?

Though in some views of this project may bring to mind Calatrava's Tenerife Concert Hall, he ventures here into different territory, approaching an almost Surrealist range of shapes. The similar element might be the helmet that looks like a head's snake. Also the types of the materials that are used in those two buildings are the same, as always white concrete, steel and glass. Both of the buildings are seen as a "monumental sculpture". 


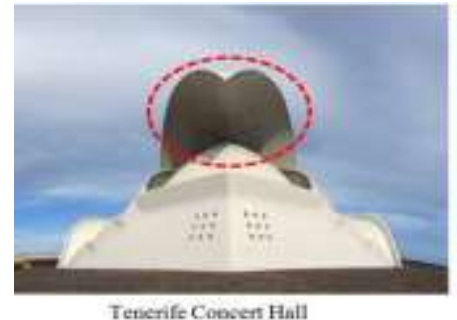

Tererife Cosert Hall

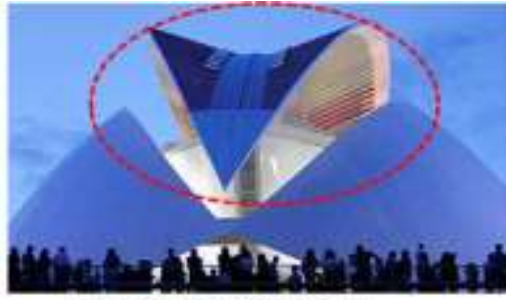

Palacio de las Arter Reine Sofia

Fig. 15. Shell and Shape

Calatrava also uses a broken tile surface, which also shows the influence of Antonio Gaudi, a figure Calatrava clearly admires. Also the Blue Mosaic Tiles are used in the interior and the exterior of the Opera House.

\subsection{El Pont De L'assut De L'or}

El Pont de l'Assut de l'Or is a suspension bridge that connects the south side with Minorca Street, whose 125 meters high pillar is the highest point in the city. It crosses the Turia Gardes, the former riverbed of Turia River. The design of the bridge is made by Santiago Calatrava, as a common design with the other bridges that has been done before. The total length of the bridge is 180 meters, and the height is 125 meters, which makes it the highest point of the city. The bridge was opened to the public in 2008. Calatrava has used the white concrete and the steel for the construction. In this structure there are 19 spans that are connected in two points, by the diagonal position between the vertical wing and the horizontal path of the bridge.

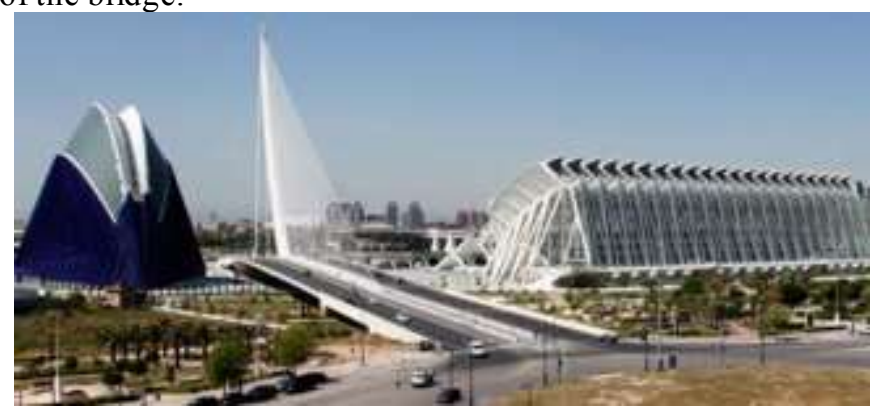

Fig. 16. El Pont de l'Assut de l'Or bridge

Which are the key elements that Calatrava uses in the design of the El Pont De L'assut De L'or?

This bridge brings in mind his famous bridge Alamillo Bridge, which is one of his earliest works. The El Pont de l'Assut de l'Or bridge, comes as a miniature of the Alamillo Bridge. Almost every element is the same. The only differences between them are the dimension and the proportion between the two edges of the triangle shape of the bridge.

The structure of El Pont de l'Assut de l'Or bridge is based in the same concepts that was designed the Alamillo Bridge. The Steel Cables are connected with the concrete construction in the same method. They are lying in diagonal position, or better to say as the hypotenuse of the triangle. Is very understandable the engineering skills that Calatrava owns.Also the horizontal plan of the bridge serves as a path for vehicles and pedestrians. 


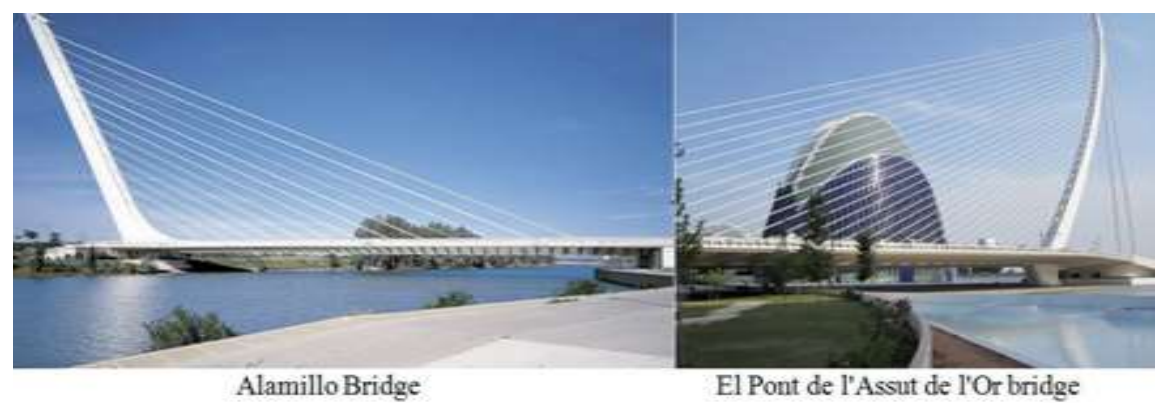

Fig. 17. Structure and shape

\section{Conclusions}

Analyzing the above buildings of the City of Arts and Science, I can conclude that the key elements that Calatrava uses in this complex are almost the key elements that Calatrava has been using in the other prior projects. These elements that are present in its recent works are the key elements that create the Calatrava's vocabulary design. Calatrava in the complex presents some similarities in: The concept that Calatrava uses in this Complex is always based in the human being. The most common element is the shape of the eye, as the architect always says that is the "eye of knowledge". In addition to the human being, is presented and the symbol of the nature forms such as the tree, the seashells, and the whale skeleton. In his projects in the center of his concept is the relation of the forms in the nature and in the human being. Studying the structure of this relation is the basement and for his structural designs. The shape, is not casual in Calatrava's designs, and also isn't as a resultant of the site limits. Calatrava's shapes are drawn as an analys is of the rapports between elements of a conceptual natural and human being. The architect brings in sketches, not a copied shape but he carefully studies not only the geometrical element but also the function that will be happening there and the sustainability in every aspect. Studying in engineering school, Calatrava is not only an architect, but he is also an engineer. His works are not only based in the principles of architecture but also they are well thought in the principles from the mind of an engineer. Calatrava skills are not only in imag ination, but also he has strength skills in realizing his works. He uses concrete and steel, as the important element. The structure elements, such as the pillars, arches are based in the concept of nature, such as tree, human body, the skeleton, etc. Calatrava always uses three main materials such as, the white concrete, steel structures, and glass. He is able to bring monumental volumes even with these materials. Calatrava mostly presents vernacular architecture, and is influenced by the Spanish architects. He develops the structuralconcept and he uses the characteristic of the materials.

While some contemporary architects, who shall remain unnamed, seek innovation in extravagant but often unusable forms, the vocabulary of Calatrava is rooted in a sense of design and engineering which precedes more from within than from an imposed and dysfunctional artistic ambition.

\section{References}

1. Jodido, Philip (1951); Santiago Calatrava: Architetto, Ingegnere, Artista

2. Tzonis, Alexander; Lefrave, Laine (1995); Movement, Structure and the Work of Santiago Calatrava

3. Tzonis, Alexander (2007); Santiago Calatrava - The Complete Works

4. The Architect's Studio, Santiago Clatrava 